OPEN ACCESS

Edited by:

Tycho M. Hoogland, Erasmus Medical Center,

Netherlands

Reviewed by:

Francesca Prestori,

University of Pavia, Italy

Laurens Bosman,

Erasmus Medical Center,

Netherlands

${ }^{*}$ Correspondence:

Yuan-Zhe Jin

y-z-jin@ybu.edu.cn

Song-Biao Cui sbcui@ybu.edu.cn

De-Lai Qiu

dlqiu@ybu.edu.cn

${ }^{t}$ These authors have contributed equally to this work.

Received: 16 May 2017 Accepted: 04 August 2017 Published: 22 August 2017

Citation: Jin $X-H$, Wang $H-W$, Zhang $X-Y$, Chu C-P, Jin Y-Z, Cui S-B and Qiu D-L (2017) Mechanisms of Spontaneous Climbing Fiber Discharge-Evoked Pauses and Output Modulation of Cerebellar

Purkinje Cell in Mice. Front. Cell. Neurosci. 11:247. doi: 10.3389/fncel.2017.00247

\section{Mechanisms of Spontaneous Climbing Fiber Discharge-Evoked Pauses and Output Modulation of Cerebellar Purkinje Cell in Mice}

\author{
Xian-Hua Jin ${ }^{1,2 \dagger}$, Hong-Wei Wang ${ }^{1,3 \dagger}$, Xin-Yuan Zhang ${ }^{1,4 \dagger}$, Chun-Ping Chu ${ }^{1}$, \\ Yuan-Zhe Jin ${ }^{1,4 *}$, Song-Biao Cui ${ }^{2 *}$ and De-Lai Qiu ${ }^{1,4 *}$ \\ ${ }^{1}$ Key Laboratory of Cellular Function and Pharmacology of Jilin Province, Yanbian University, Yanji, China, ${ }^{2}$ Department \\ of Neurology, Affiliated Hospital of Yanbian University, Yanji, China, ${ }^{3}$ Department of Endocrinology and Metabolism, Affiliated \\ Zhongshan Hospital of Dalian University, Dalian, China, ${ }^{4}$ Department of Physiology and Pathophysiology, College \\ of Medicine, Yanbian University, Yanji, China
}

Climbing fiber (CF) afferents modulate the frequency and patterns of cerebellar Purkinje cell (PC) simple spike (SS) activity, but its mechanism is unclear. In the present study, we investigated the mechanisms of spontaneous CF discharge-evoked pauses and the output modulation of cerebellar PCs in urethane-anesthetized mice using in vivo whole-cell recording techniques and pharmacological methods. Under voltage-clamp recording conditions, spontaneous CF discharge evoked strong inward currents followed by small conductance calcium-activated potassium (SK) channels that mediated outward currents. The application of a $\mathrm{GABA}_{A}$ receptor antagonist did not significantly alter the spontaneous SS firing rate, although an AMPA receptor blocker abolished complex spike (CS) activity and induced significantly increased SS firing rates and a decreased coefficient of variation (CV) SS value. Either removal of extracellular calcium or chelated intracellular calcium induced a decrease in amplitude of CS-evoked after-hyperpolarization (AHP) potential accompanied by an increase in SS firing rate. In addition, blocking SK channels activity with a selective antagonist, dequalinium decreased the amplitude of AHP and increased SS firing rate. Moreover, we found repeated CF stimulation at $1 \mathrm{~Hz}$ induced a significant decrease in the spontaneous firing rate of SS, and accompanied with an increase in CV of SS in cerebellar slices, which was also abolished by dequalinium. These results indicated that the spontaneous CF discharge contributed to decreasing SS firing rate via activation of SK channels in the cerebellar PCs in vivo in mice.

\begin{abstract}
Keywords: cerebellar Purkinje cell, whole-cell patch-clamp recording, complex spike (CS), after-hyperpolarization (AHP), simple-spike (SS), small conductance calcium-activated potassium channel (SK)
\end{abstract}

\section{INTRODUCTION}

Cerebellar Purkinje cells (PCs) exhibit spontaneous simple spike (SS) firing that is accompanied by irregular complex spike (CS) discharges in vivo (Ito, 1984). The bursting of SS firing is thought to be controlled by T-type calcium channels, as well as small conductance (SK) and large conductance (BK) calcium-activated potassium currents (Swensen and Bean, 2003). 
Under physiological conditions, the activation of BK channels requires both membrane depolarization and an increase in intracellular $\mathrm{Ca}^{2+}$, although activation of SK channels is not dependent on membrane voltage and can respond to $\mathrm{Ca}^{2+}$ entry only (Köhler et al., 1996; Vergara et al., 1998). Notably, SK channels contribute to an after-hyperpolarization (AHP) potential following bursts of action potentials and are involved in the regulation of spike firing frequency in some neurons (Stocker et al., 1999; Pedarzani et al., 2001). Additionally, dendritic ionic channels contribute to spontaneous SS activity in cerebellar slices (Womack and Khodakhah, 2002). For instance, dendritic $\mathrm{Ca}^{2+}$ influx via voltage-gated calcium channels (VGCC; Llinás and Sugimori, 1980; Usowicz et al., 1992) and P/Q-type calcium channels (Womack and Khodakhah, 2004) also contribute to SS burst firing in PCs in vitro.

Climbing fiber (CF) activation evokes distinctive high-frequency CSs followed by a pause of SS (Eccles et al., 1966), which suggests that CS activity is an important signal for the cerebellar cortex, conveying timing information from the outside to the cerebellar cortex (Welsh and Llinás, 1997) and triggering parallel fiber-PC synaptic plasticity (Hansel et al., 2001; Ito, 2001). The inhibition of CF discharges by inactivating or removing the inferior olive induces an increase in spontaneous SS frequency of PCs, revealing that CF input influences SS discharge in PCs in vivo (Colin et al., 1980; Montarolo et al., 1982; Cerminara and Rawson, 2004). Additionally, repetitive stimulus of CFs induces a progressive reduction and ultimately the total cessation of spontaneous SS activity (Colin et al., 1980; Demer et al., 1985). Under in vitro conditions, CF-induced changes in the PC SS firing rate could occur independently of network activation, although it is dependent on the level of intracellular $\mathrm{Ca}^{2+}$ (McKay et al., 2007). Repetitive CF discharges induce an increase in intracellular $\mathrm{Ca}^{2+}$ levels and enhance activation of $\mathrm{Ca}^{2+}$-dependent potassium channels, resulting in a change in SS firing properties (Hounsgaard and Midtgaard, 1989; Miyakawa et al., 1992; Maeda et al., 1999; McKay et al., 2007).

CF discharge evokes pause and AHP potential, which is assumed to be the result of recruited inhibitory interneurons by their CF inputs (Mathews et al., 2012), as well from activation of calcium-dependent SK-type $\mathrm{K}^{+}$channels (Kakizawa et al., 2007). During downregulation of the unique isoform of SK channels, $\mathrm{SK}_{2}$ induces increased SS activity in PC intrinsic plasticity (Belmeguenai et al., 2010). Additionally, the inhibition or reduction of $\mathrm{SK}_{2}$ channels abolishes spike pause plasticity, which suggests that $\mathrm{SK}_{2}$ channels may be crucial to cerebellar information storage by altering PC output (Grasselli et al., 2016). Conversely, cerebellar cortical molecular layer interneurons (MLIs) activated by parallel fibers are involved in controlling PC output via powerful feed-forward inhibition (FFI) in vitro (Häusser and Clark, 1997; Mittmann et al., 2005). The inhibition of $\mathrm{GABA}_{\mathrm{A}}$ receptor-mediated FFI decreases the PF stimulationevoked number of SS firing in mouse cerebellar PCs (Wulff et al., 2009). However, single unit recordings from cerebellar PCs reveals and average SS firing frequency that is similar between $\mathrm{GABA}_{\mathrm{A}}$ receptor $\gamma_{2}$ subunit deleted (PC- $\Delta \gamma_{2}$ ) and normal mice (Wulff et al., 2009).
Although the effects of CF activity on SS firing characteristics have been well established in vitro and in vivo by extracellular recording technique, the mechanisms of spontaneous $\mathrm{CF}$ discharge-evoked pauses and the modulation of cerebellar PCs in living animals remain unclear. In this study, we analyzed the mechanisms of spontaneous CS discharge modulation of SS activity in cerebellar PCs in urethane-anesthetized mice using in vivo whole-cell recording techniques and pharmacological methods. Results showed that either removal of extracellular calcium or chelated intracellular calcium induced a decrease in amplitude of CS-evoked AHP accompanied by an increase in SS firing rate. Inhibition of SK channels activity decreased AHP amplitude and increased the SS firing rate. These results indicated that spontaneous CF discharge contributed to decreasing the SS firing rate via activation of SK channels in cerebellar PCs in mice.

\section{MATERIALS AND METHODS}

\section{Anesthesia and Surgical Procedures}

The anesthesia and surgical procedures have been previously described (Chu et al., 2011). In brief, the experimental procedures were approved by the Animal Care and Use Committee of Jilin University and were in accordance with the animal welfare guidelines of the U.S. National Institutes of Health. The permit number is SYXK (Ji) 2007-0011. Animals were housed under a 12-h light:12-h dark cycle with free access to food and water. Either male $(n=30)$ or female $(n=30)$ adult (6 to 8 -weekold) HA/ICR mice were anesthetized with urethane $(1.3 \mathrm{~g} / \mathrm{kg}$ body weight i.p.). A watertight chamber was created and a $1-1.5-\mathrm{mm}$ craniotomy was drilled to expose the cerebellar surface corresponding to vermis VI-VII. The brain surface was constantly superfused with oxygenated artificial cerebrospinal

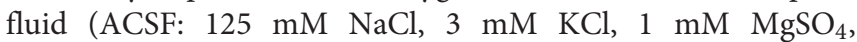
$2 \mathrm{mM} \mathrm{CaCl}_{2}, 1 \mathrm{mM} \mathrm{NaH} \mathrm{PO}_{4}, 25 \mathrm{mM} \mathrm{NaHCO}_{3}$ and $10 \mathrm{mM}$ D-glucose) using a peristaltic pump (Gilson Minipulse 3; Villiers, Le Bel, France) at $0.4 \mathrm{ml} / \mathrm{min}$. Rectal temperature was monitored and maintained at $37.0 \pm 0.2^{\circ} \mathrm{C}$ using body temperature equipment.

\section{Electrophysiological Recording in Urethane-Anesthetized Mice}

In vivo whole-cell patch-clamp recordings from PC somas ( $n=42$ cells) were performed using an Axopatch-200B amplifier (Molecular Devices, Foster City, CA, USA) in the cerebellar cortical lobule vermis VIb from 42/60 mice. We failed to obtain whole-cell recordings from PC somas in a total of 18 mice, although one PC was recorded in 42 mice for further experiments. Signals of whole-cell recordings from PCs were acquired using a Digidata 1440 series analog-to-digital interface on a personal computer with Clampex 10.3 software. Patchpipettes were made with a puller (PB-10; Narishige, Tokyo, Japan) from thick-wall borosilicate glass (GD-1.5; Narishige). Patch electrodes (4-6 M $\Omega$ ) contained a solution of the following (in $\mathrm{mM}$ ): potassium gluconate 120 , HEPES 10 , EGTA $1, \mathrm{KCl} 5$, $\mathrm{MgCl}_{2}$ 3.5, NaCl 4, biocytin 8, $\mathrm{Na}_{2} \mathrm{ATP} 4$ and $\mathrm{Na}_{2}$ GTP 0.2 
(pH 7.3 with $\mathrm{KOH}$, osmolarity adjusted to $300 \mathrm{mOsm}$ ). For BAPTA experiments, EGTA was replaced with $10 \mathrm{mM}$ BAPTA. The whole-cell recordings from PC somas were performed at depths of 250-300 $\mu \mathrm{m}$ under the pia mater membrane, and identified by regular spontaneous SS accompanied with irregular CS (Chu et al., 2011). The series resistances were in a range of $10-40 \mathrm{M} \Omega$ and compensated by $80 \%$. Membrane voltage and current were filtered at $2 \mathrm{kHz}$ and digitized at $20 \mathrm{kHz}$. Membrane resistance $\left(R_{\mathrm{m}}\right)$ was determined by applying $-100 \mathrm{pA}$ square pulses $(600 \mathrm{~ms})$ from a mean membrane potential of 60 $( \pm 0.14 \mathrm{mV} ; n=42)$ under current-clamp recording conditions (Figure 1A). The $R_{\mathrm{m}}$ was calculated from steady-state membrane potential of five responses. Spontaneous activity was calculated from a train of interspike intervals recorded for $100 \mathrm{~s}$. In addition, the whole-cell recordings from PC dendrites were identified by the attenuated backpropagating of $\mathrm{Na}^{+}$action potentials (Chu et al., 2011), which were excluded from this study.

\section{Electrophysiological Recording in Cerebellar Slices}

Cerebellar slices preparation has been previously described (Qiu and Knöpfel, 2007). Adult mice were deeply anesthetized with halothane and decapitated quickly. The cerebellum was dissected and placed in ice-cold ACSF bubbled with $95 \% \mathrm{O}_{2} / 5 \% \mathrm{CO}_{2}$. The sagittal slices of cerebellar cortex $(250 \mu \mathrm{m}$ thick) were prepared using a Vibratome (VT 1200s, Leica, Nussloch, Germany). The slices were incubated for $\geq 1 \mathrm{~h}$ in a chamber filled with $95 \% \mathrm{O}_{2} / 5 \%$ $\mathrm{CO}_{2}$ equilibrated ACSF at room temperature $\left(24-25^{\circ} \mathrm{C}\right)$ prior to recording.

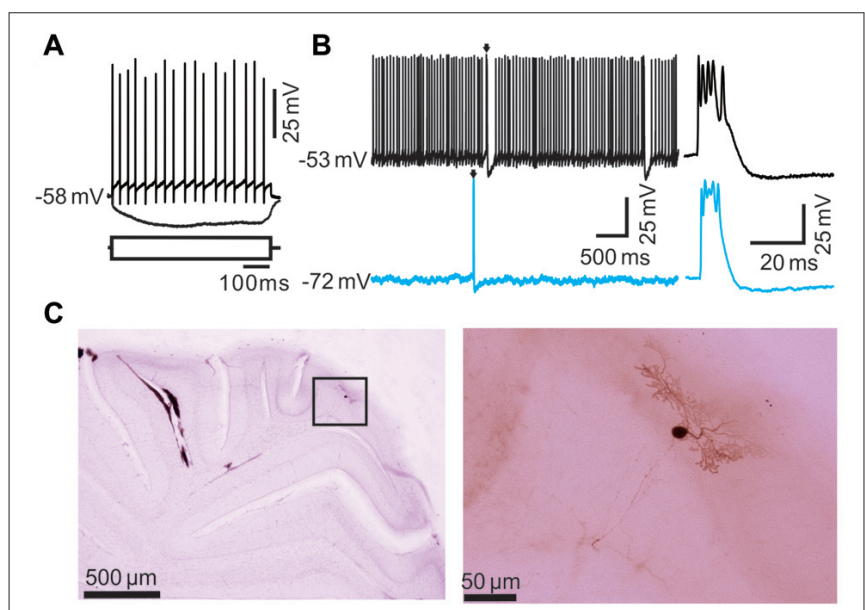

FIGURE 1 | Whole-cell recordings showed the property of cerebellar Purkinje cell (PC) spontaneous activity in living mice. (A) Whole-cell patch-clamp recording from a soma of a $\mathrm{PC}$ in response to hyperpolarizing $(-100 \mu \mathrm{A})$ and depolarizing $(+100 \mu \mathrm{A})$ current pulses. (B) Under current-clamp,

representative traces showing the spontaneous complex spike (CS; arrows) and simple spike (SS) activities when the membrane potential were clamped at $-53 \mathrm{mV}$ ( $=0 \mathrm{pA}$; upper) and $-72 \mathrm{mV}$ (lower). (C) The photomicrographs show the morphology of the cell, which is shown in (A). The left column shows an overview of the location of the biocytin-labeled cell. The right column shows the detail of the biocytin-labeled cell.
Whole-cell patch-clamp recordings from PC somas in cerebellar slices visualized using a $60 \times$ water-immersion lens through a Nikon microscopy (Eclipse FN1, Nikon Corp., Tokyo, Japan). Patch pipette resistances were 5-7 M $\Omega$ in the bath, with series resistances in the range of 10-20 M $\Omega$. Membrane potentials and/or currents were monitored with an Axopatch 700B amplifier (Molecular Devices, Foster City, CA, USA), filtered at $5 \mathrm{kHz}$, and acquired through a Digidata 1440 series analog-to-digital interface on a personal computer using Clampex 10.4 software (Molecular devices, Foster City, CA, USA). For CF electrical stimulation, current pulses $(0.2 \mathrm{~ms}$, $100 \mu \mathrm{A})$ at $1 \mathrm{~Hz}$ were delivered through a glass electrode. The stimulating electrode containing ACSF (0.1-0.5 M $\Omega$ ) was placed in the granule cell (GC) layer of the cerebellar cortex for $\mathrm{CF}$ stimulation.

\section{Drug Application}

The reagents, which included BAPTA, 1,2-bis(2aminophenoxy)ethane- $\mathrm{N}, \mathrm{N}, \mathrm{N}^{\prime}, \mathrm{N}^{\prime}$ - tetraacetic acid, gabazine (SR95531), hydrobromide (6-imino-3-(4-methoxyphenyl)$1(6 \mathrm{H})$ - pyridazinebutanoic acid hydrobromide), NBQX, (2,3-dioxo-6-nitro-1,2,3,4-tetrahydrobenzo [f]quinoxaline-7sulfonamide) and dequalinium, were purchased from SigmaAldrich (Shanghai, China). The drugs were dissolved in ACSF, and directly applied to the cerebellar surface using a peristaltic pump $(0.5 \mathrm{ml} / \mathrm{min})$ for $10 \mathrm{~min}$.

\section{Data Analysis}

The electrophysiological data were analyzed using Clampfit 10.3 software. Values are expressed as mean \pm SEM. One-way ANOVA and Mann-Whitney-Wilcoxon test (SPSS software; Chicago, IL, USA) was used to determine the level of statistical significance between groups of data. $P$-values $<0.05$ were considered to indicate a statistically significant difference between experimental groups.

\section{RESULTS}

\section{Properties of Spontaneous CS Activity of Cerebellar PCs In Vivo in Mice}

In this study, a total 42 cerebellar PCs were recorded in the cerebellar cortex vermis VIb using in vivo whole-cell patchclamp recording technique in urethane-anesthetized mice (Chu et al., 2011, 2012). According to previous studies (Ito, 1984; Chu et al., 2011; Liu et al., 2016), the PCs were identified by regular SS firing accompanied by irregular CS activity. Under current-clamp conditions $(I=0)$, the mean membrane potential was $-52.6 \pm 0.37 \mathrm{mV}(n=42$ cells $)$, and the mean frequency of SS firing was $37.5 \pm 2.8 \mathrm{~Hz}(n=42$ cells). The PCs also exhibited an irregular CS firing at a range of $0.01-1.72 \mathrm{~Hz}$ ( $n=42$ cells), accompanied by a SS pause with a mean value of $88.7 \pm 7.6 \mathrm{~ms}$ ( $n=42$ cells). We also estimated membrane resistance $\left(R_{\mathrm{m}}\right)$ of the PCs by injecting square pulses $(-100 \mathrm{pA}$, $600 \mathrm{~ms}$ ) under current clamp recording conditions (Figure 1A). The mean $R_{\mathrm{m}}$ value of PCs was $150.3 \pm 21.7 \mathrm{M} \Omega(n=42$ cells). Injection of bias currents maintained at PCs at $-70 \mathrm{mV}$ 
by inhibiting spontaneous SS activity, but did not prevent spontaneous CS activity (Figure 1B). The photomicrographs showed that the morphology of the recorded neuron was a PC (Figure 1C).

Furthermore, we analyzed the relationship between CS and SS frequencies, AHP amplitude, and time of pause. As shown in Figure 2, the spontaneous CS firing rate negatively correlated with SS frequency (Figure 2A; $R=0.75, P<0.001$ ), whereas time of pause positively correlated with AHP amplitude (Figure 2B; $R=0.69, P<0.001$ ) under current-clamp conditions. Notably, the high CS discharge rate $(\geq 0.2 \mathrm{~Hz})$ significantly correlated with frequency of SS activity (Figure 2C; $R=0.41$, $P=0.003 ; n=30$ cells), although the low CS firing rate $(<0.2 \mathrm{~Hz})$ did not significantly correlate with frequency of SS firing (Figure 2D; $R=-0.003, P=0.35 ; n=12$ cells). These results indicated that an increase in CS firing rate accompanied a decrease in SS firing frequency in cerebellar PCs in mice.

\section{Effect of Spontaneous CS Activity on SS Firing Rate in Cerebellar PCs}

Because CS discharge may affect PC SS activity through MLIs networks (Barmack and Yakhnitsa, 2003), we employed the $\mathrm{GABA}_{\mathrm{A}}$ receptor antagonist gabazine (SR95531, $\left.20 \mu \mathrm{M}\right)$ to block MLI-mediated GABAergic inputs. In the presence of gabazine, the mean frequency of SS firing was $102.6 \pm 10.1 \%$ of baseline (ACSF: $99.9 \pm 9.5 \% ; F=0.09, P=0.92$; ANOVA; $n=6$ cells; Figures $3 \mathrm{~A}, \mathbf{B})$, and the coefficient of variation $(\mathrm{CV})$ values of SS was $35.6 \pm 2.7$, which was similar to baseline (ACSF: $37.9 \pm 2.9 ; P=0.38$; Mann-Whitney-Wilcoxon test;
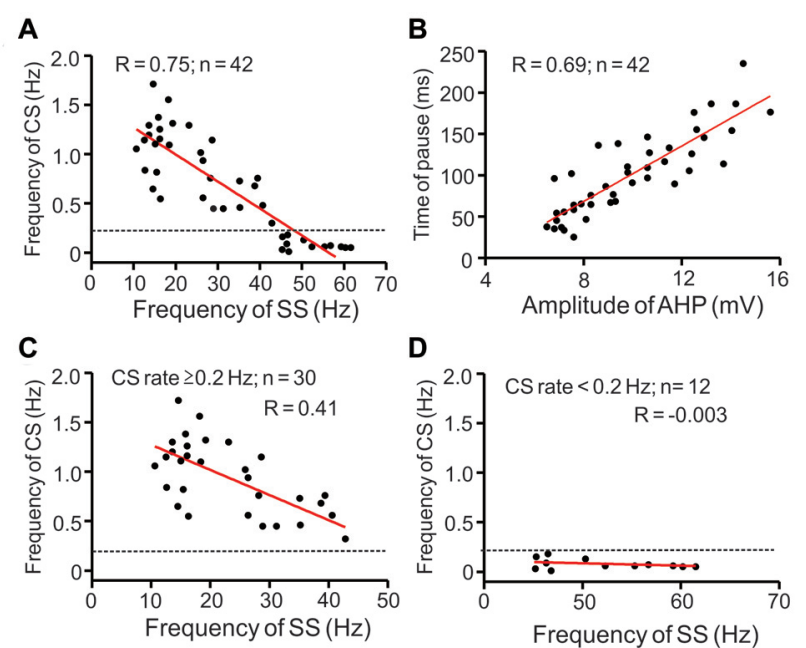

FIGURE 2 | Scatter graphs show the relationship between CS and SS frequencies, amplitude of after-hyperpolarization (AHP) and time of pause. (A) Relationship between frequency of CS and SS rate. (B) Relationship between pause and AHP amplitude. (C) Relationship between high CS discharge rate ( $\geq 0.2 \mathrm{~Hz} ; n=30$ cells) and SS rate. (D) Relationship between low CS discharge rate $(<0.2 \mathrm{~Hz} ; n=12$ cells) and SS rate. Note that the spontaneous CS firing rate negatively correlated with SS frequency, especially in PCs expressed the high CS discharge rate. $n=6$ cells; Figures $3 \mathrm{~A}, \mathrm{C})$. However, additional application of the AMPA receptor antagonist NBQX $(50 \mu \mathrm{M})$ induced a significant increase in SS firing rate and a decrease in $\mathrm{CV}$ value. In the presence of the mixture of gabazine and NBQX, the mean frequency of SS firing was $145.6 \pm 8.4 \%$ of baseline (ACSF: $99.9 \pm 9.5 \% ; F=8.3, P=0.016 ; n=6$ cells; Figures $3 \mathbf{A}, \mathbf{B})$, and the CV values of SS was $4.6 \pm 0.3$, which was significantly less than baseline (ACSF: $37.9 \pm 2.9$; $P<0.0001$; MannWhitney-Wilcoxon test; $n=6$ cells; Figures $3 \mathbf{A}, \mathbf{C})$. In the presence of gabazine, the mean pause was $86.4 \pm 9.5 \mathrm{~ms}$, which was similar to control conditions (ACSF: $197.6 \pm 8.9 \mathrm{~ms}$; $F=0.07, P=0.79$; Mann-Whitney-Wilcoxon test; $n=6$ cells; Figures $\mathbf{3 A}, \mathbf{C}$ ), and the normalized frequency of CS was

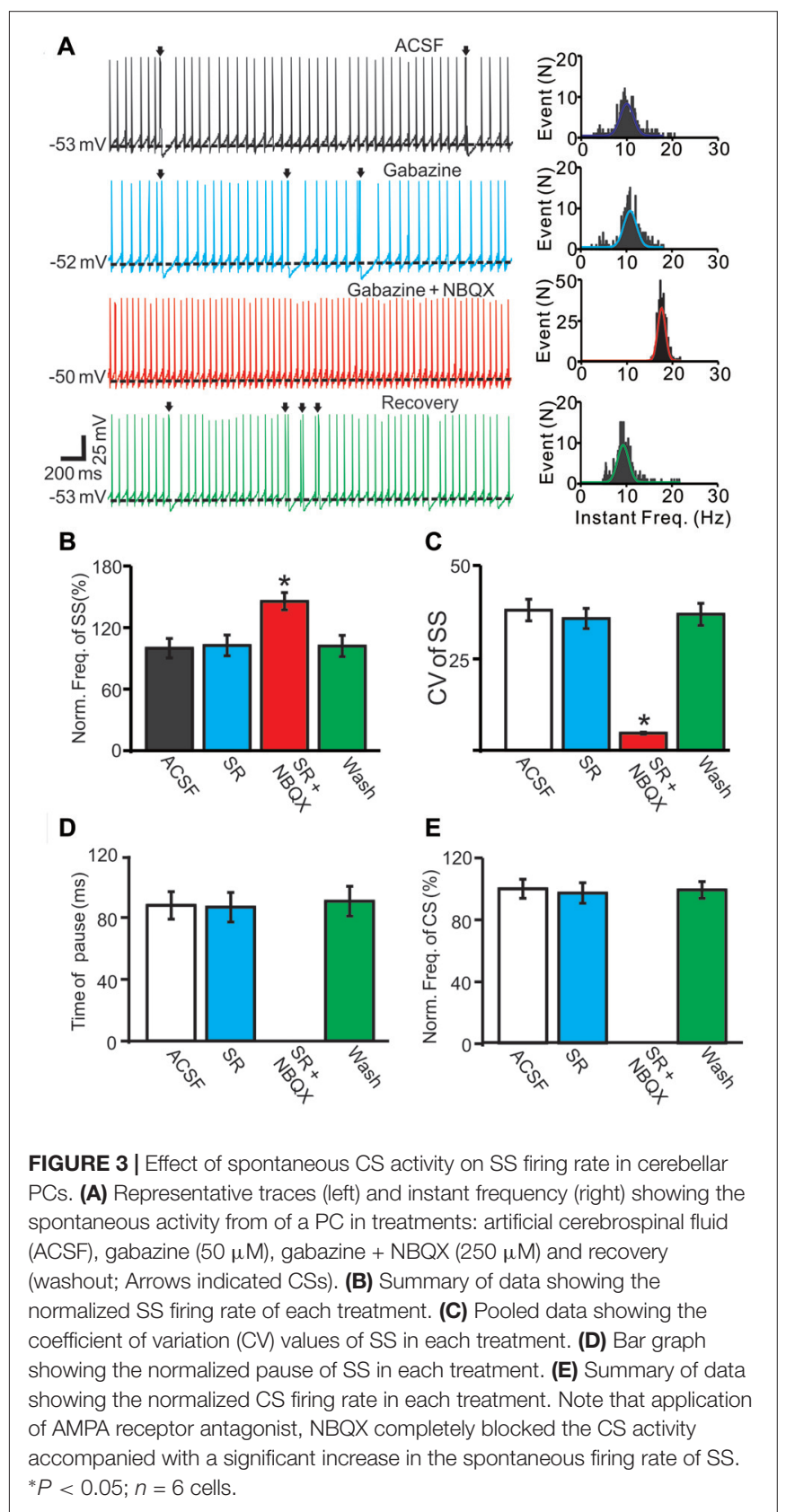


$97.3 \pm 6.6 \%$ of baseline (ACSF: $100.0 \pm 6.2 \% ; F=0.074$, $P=0.73$; ANOVA; $n=6$ cells; Figures 3A,D). Application of the mixture of gabazine and NBQX abolished CS discharge (Figures 3A,E), and no pause was observed (Figures 3A,D). These results indicated that the MLI networks contributed less to spontaneous SS firing activity, and CS discharge contributed to a decreased SS firing rate of cerebellar PCs in vivo.

Furthermore we examined the effect of CS discharge on SS firing rate by electrical stimulation of CF input in cerebellar slices. As shown in Figure 4, repeated CF stimulation at $1 \mathrm{~Hz}$ induced a significant decrease in the spontaneous firing rate of SS, the mean frequency of SS firing was $72.7 \pm 2.6 \%$ of baseline (ACSF: $99.9 \pm 1.7 \% ; F=259, P<0.0001$; ANOVA; $n=10$ cells; Figures $\mathbf{4 A , B}$ ). In addition, the mean CV value of SS was increased to $125.1 \pm 4.4 \%$ of baseline (ACSF: $100.0 \pm 3.2 \%$; $F=70.2, P=0.006$; ANOVA; $n=10$ cells; Figures 4A,C) during the repeated CF stimulation. These results indicated that CS discharge induced a significant decrease in the spontaneous firing rate of SS, and accompanied with an increase in CV of SS in cerebellar slices.

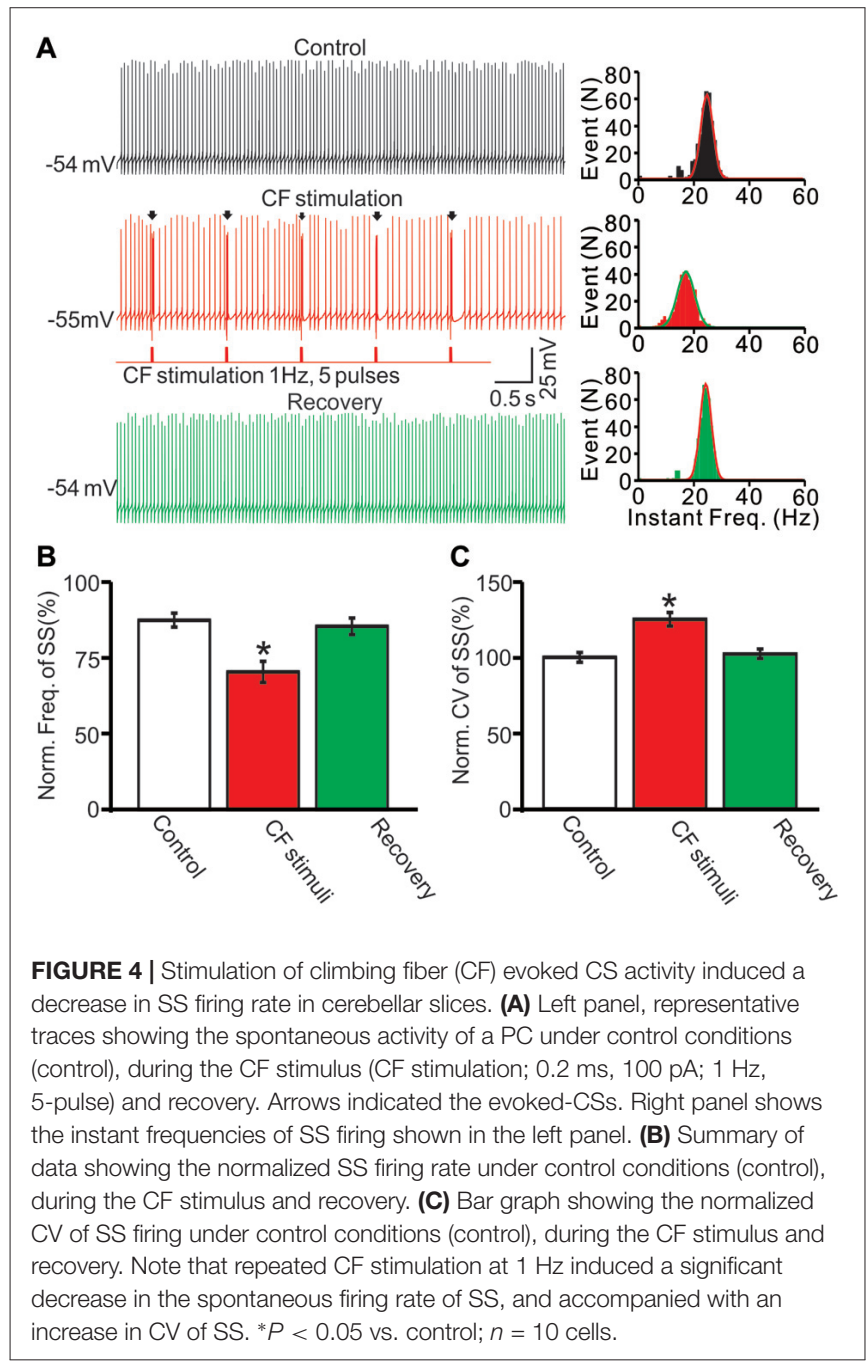

\section{Ionic Mechanism of Spontaneous CS Activity Depressed SS Firing Rate in Cerebellar PCs}

To understand the ionic mechanisms of how CF discharge modulates the SS firing rate, we examined whether the CS activity-induced decrease in SS firing rate was dependent on extracellular and intracellular calcium concentrations. We prepared a calcium-free extracellular solution by replacing calcium with an equal concentration of magnesium. Perfusion of calcium-free ACSF induced an increase in the SS firing rate (Figure 5A) accompanied by a decrease in AHP amplitude (Figure 5B). The application of a calcium-free solution resulted in an SS frequency of $168.3 \pm 9.6 \%$ of baseline (ACSF: $100.0 \pm 5.2 \% ; F=26, P=0.0007 ;$ ANOVA; $n=6$ cells; Figures $5 \mathrm{~A}, \mathrm{C})$ and a pause mean time of $24.5 \pm 4.5 \mathrm{~ms}$, which was significantly shorter than control conditions (ACSF: $61.3 \pm 9.1 \mathrm{~ms} ; P<0.001$; Mann-Whitney-Wilcoxon test; Figures 5A,D). Additionally, the application of calcium-free

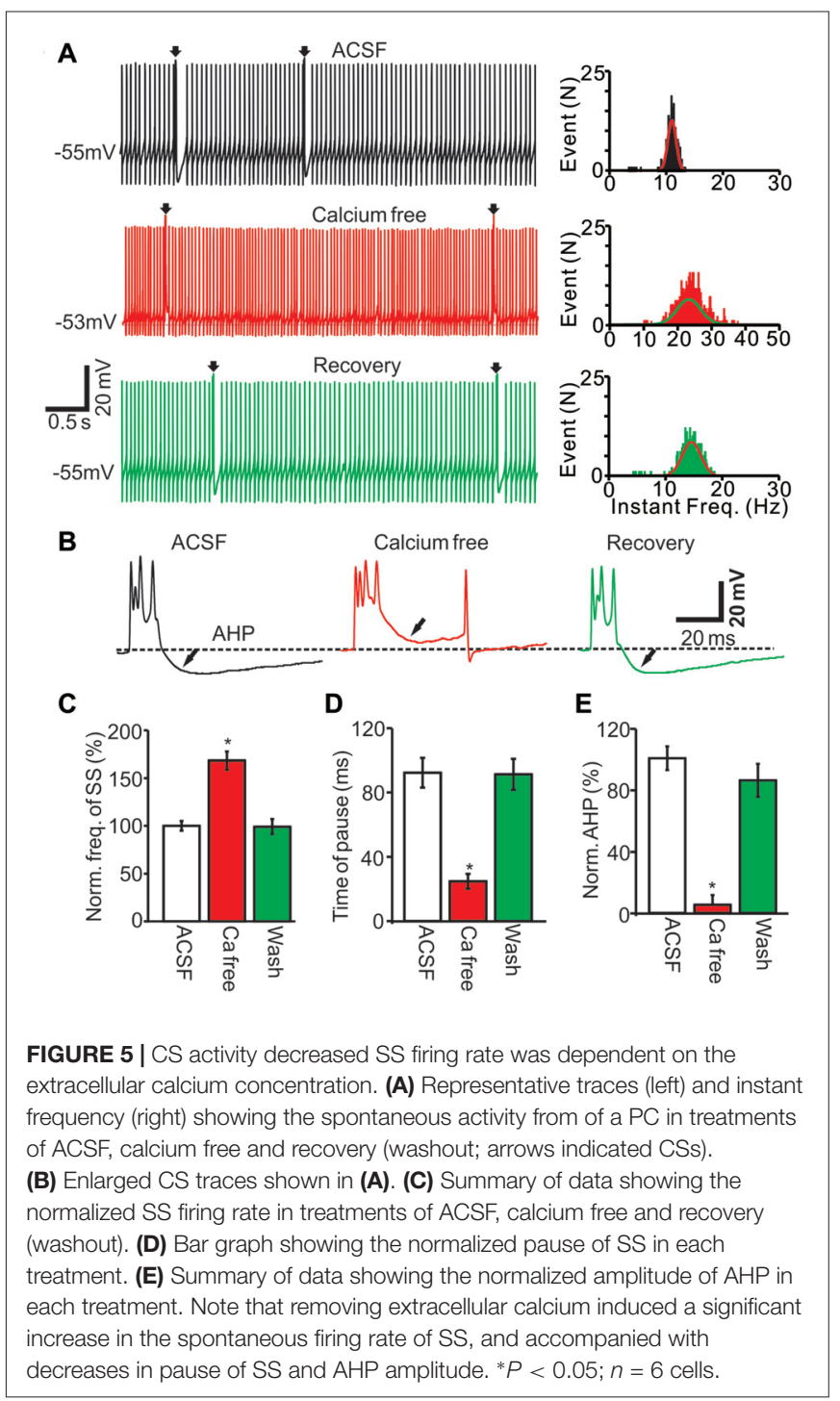


ACSF decreased the AHP amplitude to $5.2 \pm 6.4 \%$ of baseline (ACSF: $100.0 \pm 7.7 \% ; F=316.5, P<0.0001$; ANOVA; $n=6$; Figures $5 \mathrm{~A}, \mathbf{E}$ ). These results showed that the removal of extracellular calcium decreased the CS-evoked AHP amplitude and increased the SS firing rate, suggesting that the CS activitydecreased SS firing rate was dependent on the extracellular calcium influx into cerebellar PCs.

Furthermore, we examined whether intracellular calcium was required for CS activity-induced inhibition of the SS firing rate. We used a high concentration of fast-mobile $\mathrm{Ca}^{2+}$ buffer BAPTA $(10 \mathrm{mM})$ in the pipette solution and observed a change in spontaneous activity as BAPTA diffused throughout the cytoplasm (Naraghi and Neher, 1997). The BAPTA-included internal solution significantly increased the SS spike firing rate after the whole-cell configuration (Figure 6A). After $10 \mathrm{~min}$ of whole-cell configuration, the normalized SS firing rate was $178.6 \pm 12.3 \%$ of baseline (ACSF: $100.0 \pm 7.6 \% ; F=215.7$,
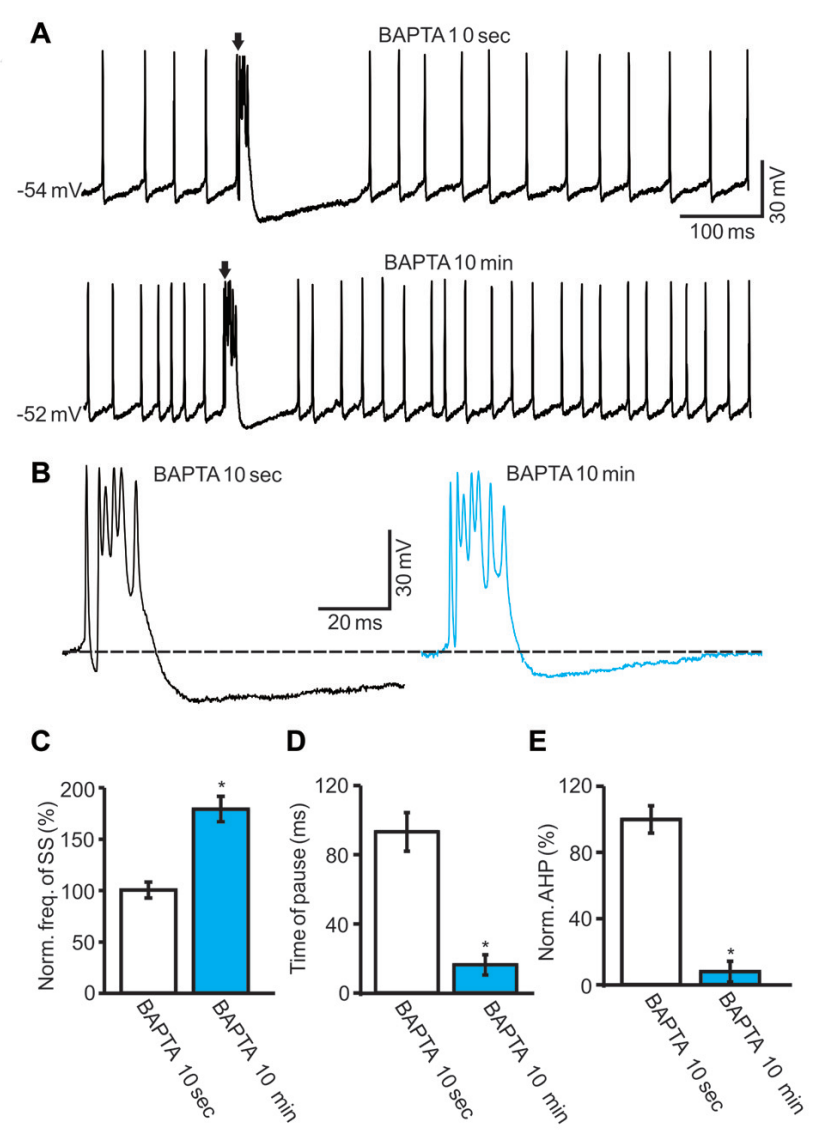

FIGURE 6 | Effect of CS activity on SS firing rate required the intracellular calcium level. (A) Under current-clamp, representative traces showing the spontaneous CS and SS activities of a PC recorded with a BAPTA-including internal solution at $10 \mathrm{~s}$ and $10 \mathrm{~min}$ after the whole-cell configuration. (B) Enlarged traces of the CS waveforms shown in (A). (C-E) Summary of data showing the normalized SS firing rate (C), pause of SS (D), amplitude of AHP (E) at $10 \mathrm{~s}$ and $10 \mathrm{~min}$ after the whole-cell configuration. Note that chelating intracellular calcium induced a significant increase in the spontaneous firing rate of SS, and accompanied with decreases in pause of SS and amplitude of AHP. ${ }^{*} P<0.05 ; n=6$ cells.
$P<0.0001$; ANOVA; $n=6$ cells; Figures 6A,C). In addition, the application of intracellular BAPTA decreased the pause of SS (Figure 6A) and the amplitude of AHP (Figure 6B). After $10 \mathrm{~min}$ of whole-cell configuration, the mean time of pause was $16.2 \pm 5.9 \mathrm{~ms}$, which was significantly shorter than control conditions (ACSF: $93.6 \pm 11.2 \mathrm{~ms} ; P<0.001$; Mann-WhitneyWilcoxon test; $n=6$ cells; Figures 6A,D), and the AHP amplitude decreased to $7.9 \pm 6.2 \%$ of baseline (ACSF: $100.0 \pm 8.2 \%$; $F=275.2, P<0.0001 ;$ ANOVA; $n=6$ cells, Figures 6B,E). Moreover, the normalized frequency of CS was $98.7 \pm 3.5 \%$ of baseline (ACSF: $100.0 \pm 6.4 \% ; F=0.065, P=0.76$; ANOVA; $n=6$ cells; not shown). These results showed that chelating intracellular calcium failed to affect the spontaneous CS firing rate, but induced a significant increase in the spontaneous firing rate of SS, which was accompanied by a decreased pause of SS and AHP amplitude.

We then tested whether SK channel activity was involved in the CS-induced decrease in SS firing rate. Similar to the perfusion of calcium-free solution, blocking SK channel activity with the selective antagonist dequalinium (10 $\mu \mathrm{M}$; Dunn, 1994), induced an increase in SS firing rate (Figure 7A) accompanied by a decreased AHP amplitude (Figure 7B). In the presence of dequalinium, the SS frequency was $176.3 \pm 8.5 \%$ of baseline (ACSF: $100.0 \pm 6.7 \% ; F=28, P=0.0008$; ANOVA; $n=6$ cells; Figures 7A,C), and the mean pause was $14.7 \pm 6.2 \mathrm{~ms}$, which was significantly shorter that control conditions (ACSF: $94.5 \pm 10.6 \mathrm{~ms} ; P<0.001 ;$ Mann-Whitney-Wilcoxon test; $n=6$ cells; Figures 7A,D). Application of dequalinium decreased the AHP amplitude to $13.5 \pm 6.9 \%$ of baseline (ACSF: $100.0 \pm 7.7 \% ; F=217, P<0.0001 ;$ ANOVA; $n=6$ cells; Figures $7 \mathrm{~A}, \mathrm{E})$. These results indicated that inhibition of SK channels induced a significant increase in the spontaneous firing rate of SS, which was accompanied by a decreased pause and AHP amplitude.

In addition, we examined the effect of repeated CF stimulation at $1 \mathrm{~Hz}$ on SS activity in the presence of dequalinium $(10 \mu \mathrm{M})$. Application of dequalinium induced an increase in SS firing rate (Figure 8A), the mean frequency of SS firing was $146.3 \pm 4.8 \%$ of baseline (ACSF: $99.9 \pm 4.2 \% ; F=204, P<0.001$; ANOVA; $n=7$ cells; Figures $\mathbf{8 A}, \mathbf{B}$ ), but without effect the mean value of $\mathrm{CV}$ (Figure 8C). Importantly, in the presence of dequalinium, CS activity at $1 \mathrm{~Hz}$ failed to induce a decrease in SS firing rate, the mean frequency of SS firing was $143.7 \pm 6.6 \%$ of baseline (ACSF: $99.9 \pm 4.2 \% ; F=204, P<0.001$; ANOVA; $n=7$ cells; Figures $\mathbf{8 A}, \mathbf{B}$ ), which was similar with dequalinium alone ( $146.3 \pm 4.8 \%$ of baseline; $P=0.75$; ANOVA; $n=7$ cells; Figures 8A,B). These results indicated that SK channel blocker abolished the CF stimulation-induced effect on the spontaneous firing activity in cerebellar slices.

\section{DISCUSSION}

Results from the present study demonstrated that spontaneous CS discharge was responsible for an evoked AHP potential and contributed to decreasing SS firing rate in cerebellar PCs in vivo. In the presence of NBQX, blocking CF input, and in the presence a selective SK channel antagonist the SS 

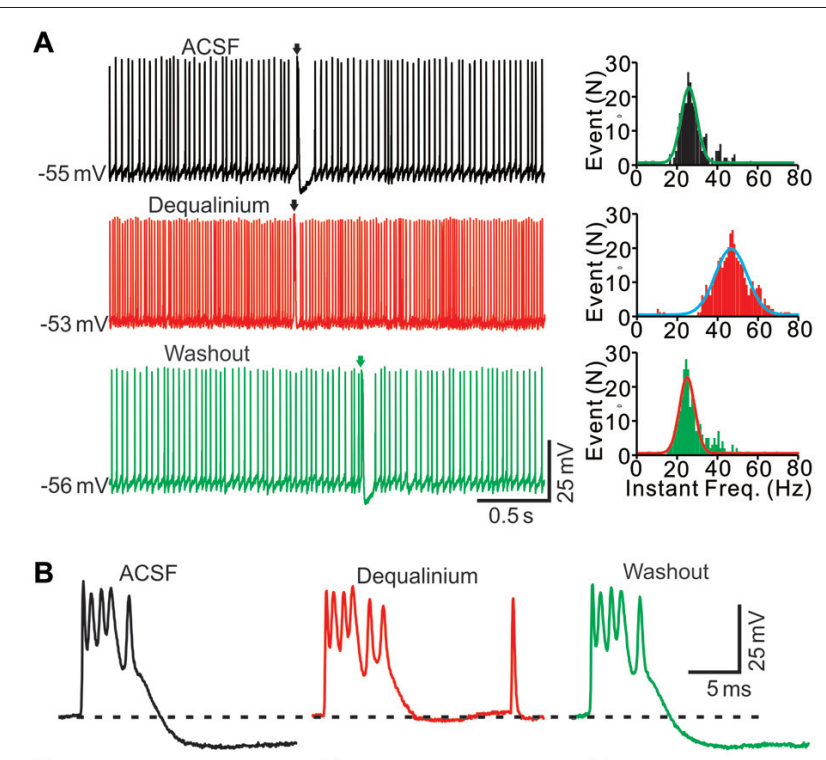

C

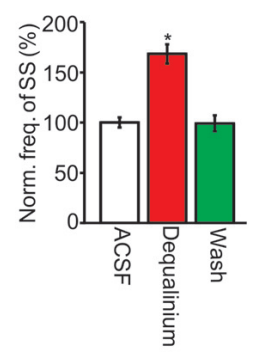

D

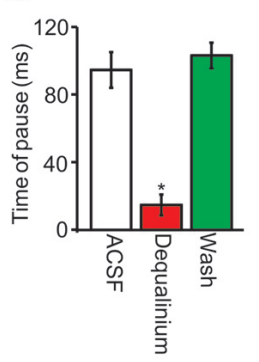

E
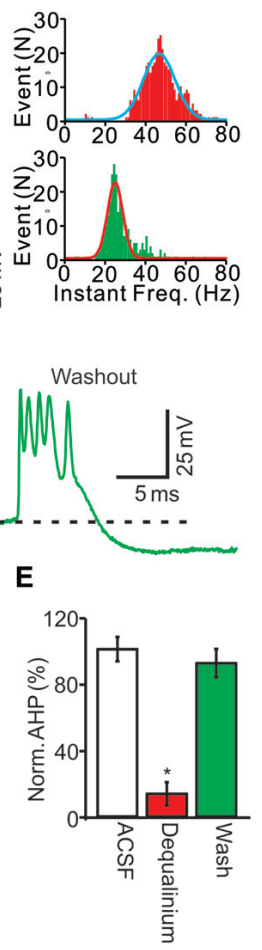

FIGURE 7 | SK channels activity was involved in CS induced the decrease in SS firing rate. (A) Representative traces (left) and instant frequency (right) showing the spontaneous activity from of a PC in treatments of ACSF, dequalinium (10 $\mu \mathrm{M})$ and washout (Arrows indicated CSs). (B) Enlarged CS traces shown in (A). (C) Summary of data showing the normalized SS firing rate in treatments of ACSF, dequalinium and washout. (D) Bar graph showing the normalized pause of SS in each treatment. (E) Summary of data showing the normalized amplitude of AHP in each treatment. Note that blockade of SK channels induced a significant increase in the spontaneous firing rate of SS, and accompanied with decreases in pause of SS and AHP amplitude. ${ }^{*} P<0.05 ; n=6$ cells.

firing rate of PCs increased. These results suggested that the spontaneous CS discharge contributed to decreasing the SS firing activity via activation of SK channels in cerebellar PCs in mice.

\section{Cerebellar PCs Exhibited Regular Spontaneous SS Firing Activity}

The PC is the focus of computation in the cerebellar cortex, providing the sole output from the cerebellar cortex to the deep cerebellar nuclei (Ito, 1984). The tonic SS activity of cerebellar PCs has been suggested to be generated by intrinsic conductance, but that was modulated by parallel fiber and CF excitatory inputs (Häusser and Clark, 1997). Under in vivo conditions, cerebellar PCs exhibited SS firing at rates of $10-150 \mathrm{~Hz}$, which was modulated by sensory stimuli such as tactile or retinal slip stimulation (Armstrong and Rawson, 1979; Ito, 1984;

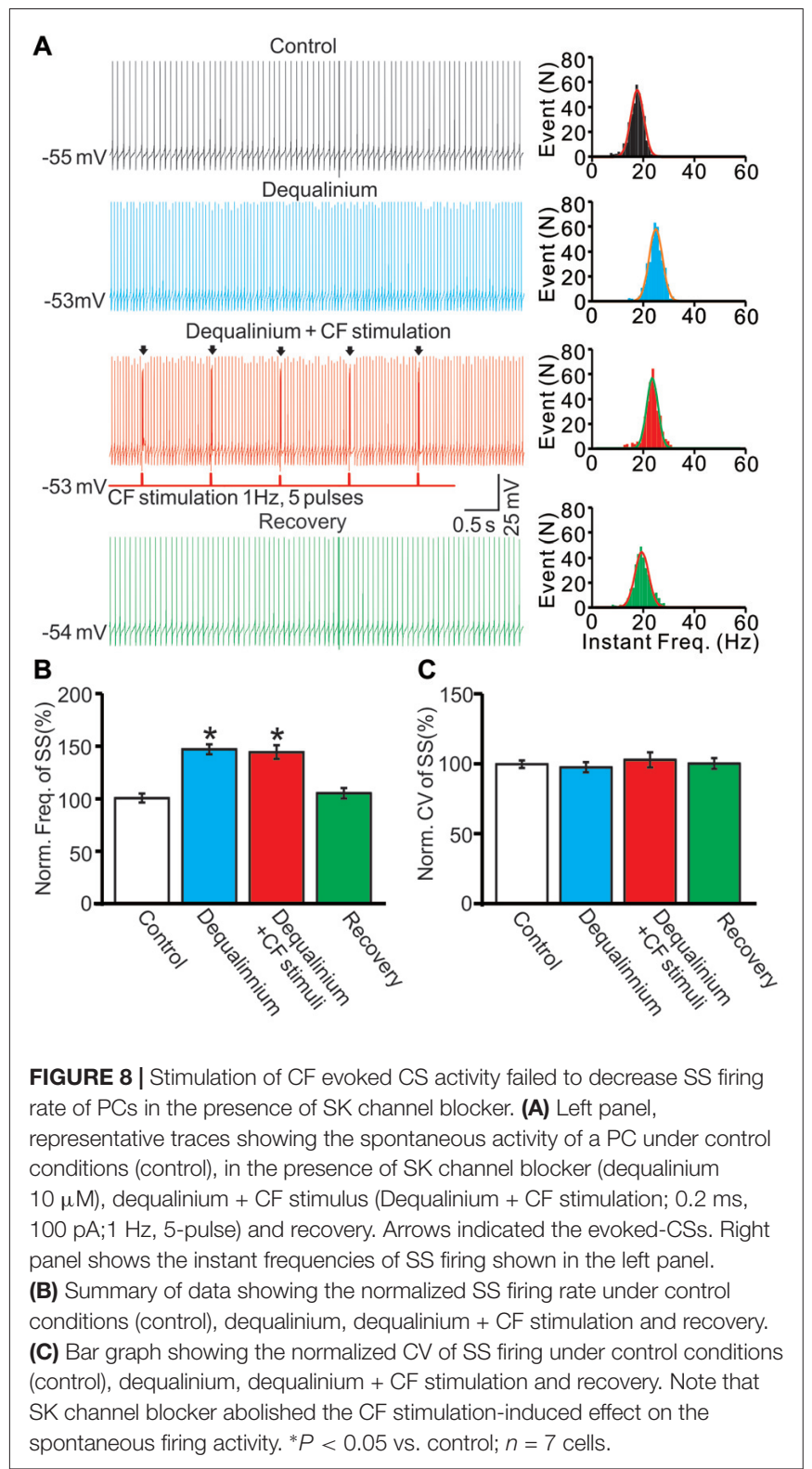

Ojakangas and Ebner, 1992; Ebner, 1998). The cerebellar PCs exhibit bistability of membrane potential and spike output, which could be induced by sensory stimulation or injuction of hyperpolarizing currents, and sometimes shown the switch between a depolarized and hyperpolarized state (Loewenstein et al., 2005; Schonewille et al., 2006; Witter and De Zeeuw, 2015). Additionally, MLIs play a critical role in modulating PC output. Stellate-type MLIs create synapses with PC dendrites, which block parallel fiber excitatory inputs onto PCs, although basket-type molecular interneurons project to the initial axonal segment and initial perisomatic inhibition of PCs. It was recently demonstrated that blocking FFI results in a significant increase in SS firing rates of cerebellar PCs in awake mice, suggesting that FFI contributes to shaping PCs output (Jelitai et al., 2016). Our present results were consistent with previous results (Santamaria et al., 2007; Chu et al., 2011), showing that the pharmacological 
blockade of GABAergic inhibition failed to increase the SS firing rate of cerebellar PCs under anesthetized conditions. We believe that these contradictory results are due to the type of anesthesia that was used. Urethane depresses neuronal excitability by activating barium-sensitive potassium leak conductance without affecting glutamate-mediated excitatory synaptic transmission or GABAA/B-mediated inhibitory synaptic transmission (Sceniak and Maciver, 2006). Under urethane-anesthetized conditions, the MLIs exhibited a spontaneous spike firing at a range of 0.08-4.26 Hz (Chu et al., 2012), and PCs fired at a mean frequency of $37.5 \mathrm{~Hz}$ (Chu et al., 2011; Liu et al., 2016; present data). Conversely, cerebellar PCs fired at a mean frequency of $61.9 \mathrm{~Hz}$, and MLIs fired at $10-30 \mathrm{~Hz}$ in the absence of movement in awake mice (Chen et al., 2016; Jelitai et al., 2016). Therefore, urethane anesthesia likely depresses the activity of PC and MLI, as well reduces the synaptic input to PCs than the awake situation.

The ionic mechanisms of SS firing activity have been well demonstrated in cerebellar PCs in vitro. The intrinsic SS firing activity of PCs is primarily driven by resurgent $\mathrm{Na}^{+}$channels, which contribute to repetitive firing by briefly reopening during the latter phase of action potential repolarization (Raman and Bean, 1997). However, the previous study illustrated that the removal of $\mathrm{Ca}^{2+}$ from extracellular solution resulted in more irregular firing behavior and a higher SS firing rate in PCs than under control conditions (Llinás and Sugimori, 1980). Therefore, the $\mathrm{Ca}^{2+}$ influx in cerebellar PCs via various $\mathrm{Ca}^{2+}$ channels near the membrane potential, at rest or hyperpolarization, is presumed to play a critical role during intrinsic SS firing activity (Llinás et al., 1989). $\mathrm{Ca}^{2+}$ influx modulates the intrinsic SS firing, which is presumed to take place following activation of $\mathrm{Ca}^{2+}$-activated $\mathrm{K}^{+}$channels, such as $\mathrm{SK}$ and $\mathrm{BK}$ channels (Crepel and Penit-Soria, 1986; Raman and Bean, 1999; Swensen and Bean, 2003). However, the SK and BK channels play a unique role in shaping the electrical properties of the PC; SK channels influence the baseline firing frequency and BK channels influence the regulation of action potential shape and modulation of the CF response (Edgerton and Reinhart, 2003). Under physiological conditions, SK channels contribute to an AHP potential following bursts of action potentials, and are involved in the regulation of spike firing frequency in cerebellar PCs (Pedarzani et al., 2001). Following the inhibition of SK channels, PCs are unable to maintain a stable, tonic, firing pattern and instead oscillate between high frequency bursts and periods of quiescence (Edgerton and Reinhart, 2003). Additionally, PC dendrites express a high density of VGCCs and generate prominent dendritic calcium spikes (Llinás and Sugimori, 1980; Usowicz et al., 1992). Therefore, dendritic VDCCs significantly contribute to spontaneous SS firing activity (Womack and Khodakhah, 2004). The inhibition of P/Q-type calcium channels abolishes dendritic calcium spikes and induces a switch from regular bursting to tonic firing or irregular bursting of SS spike firing (Womack and Khodakhah, 2004). In the present study, we applied dequalinium, a SK channel blocker, which induced a significant increase in the spontaneous firing rate of SS that was accompanied by a decreased pause of SS and AHP amplitude. Consistent with previous studies
(Dunn, 1994; Stocker et al., 1999; Pedarzani et al., 2001; Edgerton and Reinhart, 2003; Womack and Khodakhah, 2004), our results suggested that activation of SK channels was involved in initiation of SS firing discharge in cerebellar PCs in vivo.

\section{CF Discharge Contributes to Spontaneous SS Firing Activity Under In Vivo Conditions}

In the cerebellar cortex, adult PCs receive excitatory input from a single CF, which is derived from inferior olive cells (Eccles et al., 1966). CF discharge expresses high-frequency bursts, typically consisting of several spikelets (Armstrong and Rawson, 1979; Maruta et al., 2007; Mathy et al., 2009). CF activation evokes CS activity, which plays a critical role in cerebellar cortex behaviors by generating powerful EPSPs onto PCs (Simpson et al., 1996). The CS activity is presumed to represent an important signal for cerebellar cortex functions, conveying timing information from the outside to the cerebellar cortex (Welsh and Llinás, 1997) and triggering parallel fiber-PC synaptic plasticity (Hansel et al., 2001; Ito, 2001). Previous studies demonstrated that the inactivation or removal of the inferior olive induces an increase in spontaneous SS frequency of PCs, whereas reinstating CF input restores tonic levels of SS activity in living animals (Colin et al., 1980; Montarolo et al., 1982; Savio and Tempia, 1985; Cerminara and Rawson, 2004). Consistent with these (Savio and Tempia, 1985; Cerminara and Rawson, 2004), our present results showed that pharmacological blockade of CS activity with an AMPA receptor antagonist significantly increased the frequency of SS firing. Our results indicated that CS activity contributed to inhibiting the spontaneous SS firing rate, suggesting that the information conveyed by $\mathrm{CF}$ involved in the modulation of PC output in vivo (Cerminara and Rawson, 2004).

In cerebellar slices, the ionic mechanisms of CF activity reduce the frequency of SS discharge (Hounsgaard and Midtgaard, 1989; Miyakawa et al., 1992; Maeda et al., 1999; McKay et al., 2007). CS activity inhibits the SS firing rate, which has been observed in the absence of synaptic inputs, indicating that CF-induced changes in PC output can occur independent of network activation, but dependent on intracellular $\mathrm{Ca}^{2+}$ concentrations (McKay et al., 2007). Indeed, the present results showed that either removal of extracellular $\mathrm{Ca}^{2+}$ or the chelation of intracellular $\mathrm{Ca}^{2+}$ increased the SS firing rate, suggesting that a decreased SS firing rate was dependent on extracellular and intracellular calcium levels of cerebellar PCs in vivo. Under in vitro conditions, repetitive stimulation of $\mathrm{CF}$ has been shown to increase intracellular $\mathrm{Ca}^{2+}$ levels and enhance activation of SK channels, resulting in changes in SS firing properties (Hounsgaard and Midtgaard, 1989; Miyakawa et al., 1992; Maeda et al., 1999; McKay et al., 2007). In this study, the PCs were somatic clamping at $-70 \mathrm{mV}$, however, the membrane potential of the dendrites are poorly controlled under in vivo conditions (Chu et al., 2011). Thus, CF activation induces membrane depolarization, opening of VDCCs and the subsequent elevation in intracellular calcium triggers SK channel activation. Moreover, the CF-induced strong depolarization 
could evoke $\mathrm{Ca}^{2+}$ influx from CF-PC synaptic NMDARs, which contributes to elevation in intracellular calcium and activating SK channel (Miyakawa et al., 1992; Maeda et al., 1999; Liu et al., 2016). Therefore, the CS activity-induced elevations in intracellular $\mathrm{Ca}^{2+}$ are thought to enhance activation of SK channels, thereby increasing AHP generation and setting a lower firing rate of SS (Hounsgaard and Midtgaard, 1989). Results from the present study showed that inhibition of SK channels induced a significant increase in spontaneous SS frequency accompanied by a decreased CS-evoked pause and AHP amplitude. In addition, our results showed that repeated CF stimulation at $1 \mathrm{~Hz}$ induced a significant decrease in the spontaneous firing rate of SS, and accompanied with an increase in CV of SS in cerebellar slices, which was also abolished by dequalinium. These results were consistent with previous studies (Hounsgaard and Midtgaard, 1989; McKay et al., 2007), suggesting that activation of SK channels was involved in the CS activity-induced decrease in SS firing rate in cerebellar PCs in vivo.

Our results also showed that blockade of GABAergic inhibitory inputs did not significantly affect PC frequency, although blockade of excitatory inputs induced an increase in SS firing rate. This suggested that inhibition of CF inputs contributes to an increased SS firing rate. GCs are relay cells with very low spontaneous activity in the absence of sensory inputs in living animals (Bower and Woolston, 1983; Chadderton et al., 2004; van Beugen et al., 2013). Therefore, mossy fiberGC-PF excitatory inputs contribute less to SS firing in PCs under anesthetized conditions. Importantly, mossy fiber-GC-PF excitatory inputs are thought to increase the SS firing rate in PCs, and inhibition of these inputs should decrease the SS rate in PCs. Thus, the increased SS firing rate following NBQX treatment was not due to the inhibition of PF excitatory inputs.

\section{REFERENCES}

Armstrong, D. M., and Rawson, J. A. (1979). Activity patterns of cerebellar cortical neurones and climbing fibre afferents in the awake cat. J. Physiol. 289, 425-448. doi: 10.1113/jphysiol.1979.sp012745

Barmack, N. H., and Yakhnitsa, V. (2003). Cerebellar climbing fibers modulate simple spikes in Purkinje cells. J. Neurosci. 23, 7904-7916.

Belmeguenai, A., Hosy, E., Bengtsson, F., Pedroarena, C. M., Piochon, C., Teuling, E., et al. (2010). Intrinsic plasticity complements long-term potentiation in parallel fiber input gain control in cerebellar Purkinje cells. J. Neurosci. 30, 13630-13643. doi: 10.1523/jneurosci.3226-10.2010

Bower, J. M., and Woolston, D. C. (1983). Congruence of spatial organization of tactile projections to granule cell and Purkinje cell layers of cerebellar hemispheres of the albino rat: vertical organization of cerebellar cortex. J. Neurophysiol. 49, 745-766.

Cerminara, N. L., and Rawson, J. A. (2004). Evidence that climbing fibers control an intrinsic spike generator in cerebellar Purkinje cells. J. Neurosci. 24, 4510-4517. doi: 10.1523/jneurosci.4530-03.2004

Chadderton, P., Margrie, T. W., and Häusser, M. (2004). Integration of quanta in cerebellar granule cells during sensory processing. Nature 428, 856-860. doi: 10.1038/nature02442

Chen, S., Augustine, G. J., and Chadderton, P. (2016). The cerebellum linearly encodes whisker position during voluntary movement. Elife 5:e10509. doi: 10.7554/elife.10509

Chu, C.-P., Bing, Y.-H., Liu, Q.-R., and Qiu, D.-L. (2011). Synaptic responses evoked by tactile stimuli in Purkinje cells in mouse cerebellar cortex Crus II in vivo. PLoS One 6:e22752. doi: 10.1371/journal.pone.0022752

\section{Physiological Significance of CF Discharge Modulates SS Firing Activity}

$\mathrm{CF}$ activity is assumed to carry information that induces PCs to generate optimal PF input patterns (Ito, 1984). The present results showed that $\mathrm{CF}$ input to PCs regulates the SS firing behavior, suggesting that a loss of $\mathrm{CF}$ input could result in a fundamental change in spontaneous SS output, as well as deficits in motor coordination (McKay et al., 2007). Indeed, human cerebellar impairments and ataxias in some types of motor learning have been associated with marked atrophy of the inferior olive (Llinás et al., 1975; Martin et al., 1996; Manto, 2005). CF activity also provides widespread $\mathrm{Ca}^{2+}$ transients, which are required for PF-LTD induction, and this is assumed to mediate forms of cerebellar motor learning (Ito et al., 1982; Sakurai, 1990; Konnerth et al., 1992; Miyakawa et al., 1992; Ito, 2002). Collectively, spontaneous CS discharge was shown to modulate SS firing activity via activation of SK channels in cerebellar PCs, which further influences cerebellar functions and motor learning in living animals.

\section{AUTHOR CONTRIBUTIONS}

S-BC and D-LQ: conceived and designed the experiments. X-HJ, $\mathrm{H}-\mathrm{WW}$ and $\mathrm{X}-\mathrm{YZ}$ : performed the experiments. C-PC and D-LQ: analyzed the data. Y-ZJ: contributed reagents/materials/analysis tools. X-HJ, H-WW and D-LQ: wrote the manuscript.

\section{ACKNOWLEDGMENTS}

This work was supported by the International S \& T Cooperation Program of China (2016YFE0128600) and the National Natural Science Foundations of China $(31460261 ; 81160142 ; 31260245$; 81260208).

Chu, C.-P., Bing, Y.-H., Liu, H., and Qiu, D.-L. (2012). Roles of molecular layer interneurons in sensory information processing in mouse cerebellar cortex Crus II in vivo. PLoS One 5:e37031. doi: 10.1371/journal.pone. 0037031

Colin, F., Manil, J., and Desclin, J. C. (1980). The olivocerebellar system. I. Delayed and slow inhibitory effects: an overlooked salient feature of cerebellar climbing fibers. Brain Res. 187, 3-27. doi: 10.1016/0006-8993(80) 90491-6

Crepel, F., and Penit-Soria, J. (1986). Inward rectification and low threshold calcium conductance in rat cerebellar Purkinje cells. An in vitro study. J. Physiol. 372, 1-23. doi: 10.1113/jphysiol.1986.sp015993

Demer, J. L., Echelman, D. A., and Robinson, D. A. (1985). Effects of electrical stimulation and reversible lesions of the olivocerebellar pathway on Purkinje cell activity in the flocculus of the cat. Brain Res. 346, 22-31. doi: 10.1016/00068993(85)91090-x

Dunn, P. M. (1994). Dequalinium, a selective blocker of the slow afterhyperpolarization in rat sympathetic neurones in culture. Eur. J. Pharmacol. 252, 189-194. doi: 10.1016/0014-2999(94) 90596-7

Ebner, T. J. (1998). A role for the cerebellum in the control of limb movement velocity. Curr. Opin. Neurobiol. 8, 762-769. doi: 10.1016/s0959-4388(98) 80119-0

Eccles, J. C., Llinás, R., and Sasaki, K. (1966). The excitatory synaptic action of climbing fibres on the Purkinje cells of the cerebellum. J. Physiol. 182, 268-296. doi: 10.1113/jphysiol.1966.sp007824

Edgerton, J. R., and Reinhart, P. H. (2003). Distinct contributions of small and large conductance $\mathrm{Ca}^{2+}$-activated $\mathrm{K}^{+}$channels to rat Purkinje 
neuron function. J. Physiol. 548, 53-69. doi: 10.1113/jphysiol.2002. 027854

Grasselli, G., He, Q., Wan, V., Adelman, J. P., Ohtsuki, G., and Hansel, C. (2016). Activity-dependent plasticity of spike pauses in cerebellar purkinje cells. Cell Rep. 14, 2546-2553. doi: 10.1016/j.celrep.2016. 02.054

Hansel, C., Linden, D. J., and D’Angelo, E. (2001). Beyond parallel fiber LTD: the diversity of synaptic and non-synaptic plasticity in the cerebellum. Nat. Neurosci. 4, 467-475. doi: 10.1038/87419

Häusser, M., and Clark, B. A. (1997). Tonic synaptic inhibition modulates neuronal output pattern and spatiotemporal synaptic integration. Neuron 19, 665-678. doi: 10.1016/s0896-6273(00)80379-7

Hounsgaard, J., and Midtgaard, J. (1989). Synaptic control of excitability in turtle cerebellar Purkinje cells. J. Physiol. 409, 157-170. doi: 10.1113/jphysiol.1989. sp017490

Ito, M. (1984). The Cerebellum and Neural Control. New York, NY: Raven Press.

Ito, M. (2001). Cerebellar long-term depression: characterization, signal transduction, and functional roles. Physiol. Rev. 81, 1143-1195.

Ito, M. (2002). The molecular organization of cerebellar long-term depression. Nat. Rev. Neurosci. 3, 896-902. doi: 10.1038/nrn962

Ito, M., Sakurai, M., and Tongroach, P. (1982). Climbing fibre induced depression of both mossy fibre responsiveness and glutamate sensitivity of cerebellar Purkinje cells. J. Physiol. 324, 113-134. doi: 10.1113/jphysiol.1982. sp014103

Jelitai, M., Puggioni, P., Ishikawa, T., Rinaldi, A., and Duguid, I. (2016). Dendritic excitation-inhibition balance shapes cerebellar output during motor behaviour. Nat. Commun. 7:13722. doi: 10.1038/ncomms13722

Kakizawa, S., Kishimoto, Y., Hashimoto, K., Miyazaki, T., Furutani, K., Shimizu, H., et al. (2007). Junctophilin-mediated channel crosstalk essential for cerebellar synaptic plasticity. EMBO J. 26, 1924-1933. doi: 10.1038/sj.emboj. 7601639

Köhler, M., Hirschberg, B., Bond, C. T., Kinzie, J. M., Marrion, N. V., Maylie, J., et al. (1996). Small-conductance, calcium-activated potassium channels from mammalian brain. Science 273, 1709-1714. doi: 10.1126/science.273.52 82.1709

Konnerth, A., Dreessen, J., and Augustine, G. J. (1992). Brief dendritic calcium signals initiate long-lasting synaptic depression in cerebellar Purkinje cells. Proc. Natl. Acad. Sci. U S A 89, 7051-7055. doi: 10.1073/pnas.89. 15.7051

Liu, H., Lan, Y., Bing, Y.-H., Chu, C.-P., and Qiu, D.-L. (2016). N-methyl-DAspartate receptors contribute to complex spike signaling in cerebellar purkinje cells: an in vivo study in mice. Front. Cell. Neurosci. 10:172. doi: 10.3389/fncel. 2016.00172

Llinás, R., and Sugimori, M. (1980). Electrophysiological properties of in vitro Purkinje cell dendrites in mammalian cerebellar slices. J. Physiol. 305, 197-213. doi: 10.1113/jphysiol.1980.sp013358

Llinás, R. R., Sugimori, M., and Cherksey, B. (1989). Voltage-dependent calcium conductances in mammalian neurons. The P channel. Ann. N Y Acad. Sci. 560, 103-111. doi: 10.1111/j.1749-6632.1989.tb24084.x

Llinás, R., Walton, K., Hillman, D. E., and Sotelo, C. (1975). Inferior olive: its role in motor learning. Science 190, 1230-1231. doi: 10.1126/science. 128123

Loewenstein, Y., Mahon, S., Chadderton, P., Kitamura, K., Sompolinsky, H., Yarom, Y., et al. (2005). Bistability of cerebellar Purkinje cells modulated by sensory stimulation. Nat. Neurosci. 8, 202-211. doi: 10.1038/ nn 1393

Maeda, H., Ellis-Davies, G. C. R., Ito, K., Miyashita, Y., and Kasai, H. (1999). Supralinear $\mathrm{Ca}^{2+}$ signaling by cooperative and mobile $\mathrm{Ca}^{2+}$ buffering in Purkinje neurons. Neuron 24, 989-1002. doi: 10.1016/s0896-6273(00)81045-4

Manto, M. U. (2005). The wide spectrum of spinocerebellar ataxias (SCAs). Cerebellum 4, 2-6. doi: 10.1080/14734220510007914

Martin, T. A., Keating, J. G., Goodkin, H. P., Bastian, A. J., and Thach, W. T. (1996). Throwing while looking through prisms. I. Focal olivocerebellar lesions impair adaptation. Brain 119, 1183-1198. doi: 10.1093/brain/119. 4.1183

Maruta, J., Hensbroek, R. A., and Simpson, J. I. (2007). Intraburst and interburst signaling by climbing fibers. J. Neurosci. 27, 11263-11270. doi: 10.1523/JNEUROSCI.2559-07.2007
Mathews, P. J., Lee, K. H., Peng, Z., Houser, C. R., and Otis, T. S. (2012). Effects of climbing fiber driven inhibition on Purkinje neuron spiking. J. Neurosci. 32, 17988-17997. doi: 10.1523/jneurosci.3916-12.2012

Mathy, A., Ho, S. S., Davie, J. T., Duguid, I. C., Clark, B. A., and Häusser, M. (2009). Encoding of oscillations by axonal bursts in inferior olive neurons. Neuron 62, 388-399. doi: 10.1016/j.neuron.2009.03.023

McKay, B. E., Engbers, J. D. T., Mehaffey, W. H., Gordon, G. R. J., Molineux, M. L., Bains, J. S., et al. (2007). Climbing fiber discharge regulates cerebellar functions by controlling the intrinsic characteristics of Purkinje cell output. J. Neurophysiol. 97, 2590-2604. doi: 10.1152/jn.00 627.2006

Mittmann, W., Koch, U., and Häusser, M. (2005). Feed-forward inhibition shapes the spike output of cerebellar Purkinje cells. J. Physiol. 563, 369-378. doi: 10.1113/jphysiol.2004.075028

Miyakawa, H., Lev-Ram, V., Lasser-Ross, N., and Ross, W. N. (1992). Calcium transients evoked by climbing fiber and parallel fiber synaptic inputs in guinea pig cerebellar Purkinje neurons. J. Neurophysiol. 68, 1178-1189.

Montarolo, P. G., Palestini, M., and Strata, P. (1982). The inhibitory effect of the olivocerebellar input on the cerebellar Purkinje cells in the rat. J. Physiol. 332, 187-202. doi: 10.1113/jphysiol.1982.sp014409

Naraghi, M., and Neher, E. (1997). Linearized buffered $\mathrm{Ca}^{2+}$ diffusion in microdomains and its implications for calculation of $\left[\mathrm{Ca}^{2+}\right]$ at the mouth of a calcium channel. J. Neurosci. 17, 6961-6973.

Ojakangas, C. L., and Ebner, T. J. (1992). Purkinje cell complex and simple spike changes during a voluntary arm movement learning task in the monkey. J. Neurophysiol. 68, 2222-2236.

Pedarzani, P., Mosbacher, J., Rivard, A., Cingolani, L. A., Oliver, D., Stocker, M., et al. (2001). Control of electrical activity in central neurons by modulating the gating of small conductance $\mathrm{Ca}^{2+}$-activated $\mathrm{K}^{+}$channels. J. Biol. Chem. 276, 9762-9769. doi: 10.1074/jbc.m010001200

Qiu, D.-L., and Knöpfel, T. (2007). An NMDA receptor/nitric oxide cascade in presynaptic parallel fiber-Purkinje neuron long-term potentiation. J. Neurosci. 27, 3408-3415. doi: 10.1523/JNEUROSCI.4831-06.2007

Raman, I. M., and Bean, B. P. (1997). Resurgent sodium current and action potential formation in dissociated cerebellar Purkinje neurons. J. Neurosci. 17, 4517-4526.

Raman, I. M., and Bean, B. P. (1999). Ionic currents underlying spontaneous action potentials in isolated cerebellar Purkinje neurons. J. Neurosci. 19, 1663-1674

Sakurai, M. (1990). Calcium is an intracellular mediator of the climbing fiber in induction of cerebellar long-term depression. Proc. Natl. Acad. Sci. U S A 87, 3383-3385. doi: 10.1073/pnas.87.9.3383

Santamaria, F., Tripp, P. G., and Bower, J. M. (2007). Feedforward inhibition controls the spread of granule cell-induced Purkinje cell activity in the cerebellar cortex. J. Neurophysiol. 97, 248-263. doi: 10.1152/jn.01098.2005

Savio, T., and Tempia, F. (1985). On the Purkinje cell activity increase induced by suppression of inferior olive activity. Exp. Brain Res. 57, 456-463. doi: $10.1007 / \mathrm{bf} 00237832$

Sceniak, M. P., and Maciver, M. B. (2006). Cellular actions of urethane on rat visual cortical neurons in vitro. J. Neurophysiol. 95, 3865-3874. doi: 10.1152/jn.01 196.2005

Schonewille, M., Khosrovani, S., Winkelman, B. H., Hoebeek, F. E., De Jeu, M. T., Larsen, I. M., et al. (2006). Purkinje cells in awake behaving animals operate at the upstate membrane potential. Nat. Neurosci. 9, 459-461. doi: 10.1038/nn0406-461

Simpson, J. I., Wylie, D. R., and De Zeeuw, C. I. (1996). On climbing fiber signals and their consequence(s). Behav. Brain Sci. 19, 384-398. doi: $10.1017 /$ s0140525x00081486

Stocker, M., Krause, M., and Pedarzani, P. (1999). An apamin-sensitive $\mathrm{Ca}^{2+}$. activated $\mathrm{K}^{+}$current in hippocampal pyramidal neurons. Proc. Natl. Acad. Sci. U S A 96, 4662-4667. doi: 10.1073/pnas.96.8.4662

Swensen, A. M., and Bean, B. P. (2003). Ionic mechanisms of burst firing in dissociated Purkinje neurons. J. Neurosci. 23, 9650-9663.

Usowicz, M. M., Sugimori, M., Cherksey, B., and Llinás, R. (1992). P-type calcium channels in the somata and dendrites of adult cerebellar Purkinje cells. Neuron 9, 1185-1199. doi: 10.1016/0896-6273(92) 90076-p 
van Beugen, B. J., Gao, Z., Boele, H. J., Hoebeek, F., and De Zeeuw, C. I. (2013). High frequency burst firing of granule cells ensures transmission at the parallel fiber to purkinje cell synapse at the cost of temporal coding. Front. Neural Circuits 7:95. doi: 10.3389/fncir.2013.00095

Vergara, C., Latorre, R., Marrion, N. V., and Adelman, J. P. (1998). Calcium-activated potassium channels. Curr. Opin. Neurobiol. 8, 321-329. doi: 10.1016/S0959-4388(98)80056-1

Welsh, J. P., and Llinás, R. (1997). Some organizing principles for the control of movement based on olivocerebellar physiology. Prog. Brain Res. 114, 449-461. doi: 10.1016/s0079-6123(08)63380-4

Witter, L., and De Zeeuw, C. I. (2015). In vivo differences in inputs and spiking between neurons in lobules VI/VII of neocerebellum and lobule $\mathrm{X}$ of archaeocerebellum. Cerebellum 14, 506-515. doi: 10.1007/s12311015-0654-z

Womack, M., and Khodakhah, K. (2002). Active contribution of dendrites to the tonic and trimodal patterns of activity in cerebellar Purkinje neurons. J. Neurosci. 22, 10603-10612.

Womack, M. D., and Khodakhah, K. (2004). Dendritic control of spontaneous bursting in cerebellar Purkinje cells. J. Neurosci. 24, 3511-3521. doi: 10.1523/jneurosci.0290-04.2004
Wulff, P., Schonewille, M., Renzi, M., Viltono, L., Sassoè-Pognetto, M., Badura, A., et al. (2009). Synaptic inhibition of Purkinje cells mediates consolidation of vestibulo-cerebellar motor learning. Nat. Neurosci. 12, 1042-1049. doi: 10.1038/nn.2348

Conflict of Interest Statement: The authors declare that the research was conducted in the absence of any commercial or financial relationships that could be construed as a potential conflict of interest.

The reviewer LB and handling Editor declared their shared affiliation, and the handling Editor states that the process nevertheless met the standards of a fair and objective review.

Copyright (C) 2017 Jin, Wang, Zhang, Chu, Jin, Cui and Qiu. This is an open-access article distributed under the terms of the Creative Commons Attribution License (CC BY). The use, distribution or reproduction in other forums is permitted, provided the original author(s) or licensor are credited and that the original publication in this journal is cited, in accordance with accepted academic practice. No use, distribution or reproduction is permitted which does not comply with these terms. 